Supporting information for:

\title{
Redox based electrochemical affinity sensor for detection of aqueous pertechnetate anion
}

Sayandev Chatterjee ${ }^{\dagger}{ }^{*}$ Meghan S. Fujimoto $^{\dagger}$, Yingge Du ${ }^{\ddagger}$, Gabriel B. Hall ${ }^{\dagger}$, Nabajit Lahiri ${ }^{\ddagger}$, Eric D. Walter ${ }^{\star}$, Libor Kovarik ${ }^{\star}$

$\dagger$ †nergy and Environment Directorate, Pacific Northwest National Laboratory, Richland, WA 99352, USA.

E-mail: Sayandev.Chatterjee@pnnl.gov

\#nvironmental and Molecular Sciences Laboratory, Pacific Northwest National Laboratory, Richland, WA 99352, USA

Table S1. Major contaminants present in the well 299-W19-36 at the Hanford site in Washington ${ }^{28,60}$ (Reproduced from Ref. 28 with permission from The Royal Society of Chemistry.)

\begin{tabular}{|c|c|c|}
\hline Constituent & $\begin{array}{c}\text { Concentration } \\
(\boldsymbol{\mu g} / \mathbf{L})\end{array}$ & $\begin{array}{c}\text { Molarity } \\
(\mathbf{M})\end{array}$ \\
\hline Barium & 113 & $8.23 \times 10^{-07}$ \\
\hline Calcium & 122000 & $3.04 \times 10^{-03}$ \\
\hline Chloride & 181000 & $5.11 \times 10^{-03}$ \\
\hline Total Cr & 17.3 & $3.33 \times 10^{-07}$ \\
\hline Cr(VI) & 0.05 & $9.62 \times 10^{-10}$ \\
\hline Magnesium & 36400 & $1.50 \times 10^{-03}$ \\
\hline Molybdenum & 65.9 & $6.87 \times 10^{-07}$ \\
\hline Nitrate & 317000 & $5.11 \times 10^{-03}$ \\
\hline Potassium & 7010 & $1.79 \times 10^{-04}$ \\
\hline Sodium & 118000 & $5.13 \times 10^{-03}$ \\
\hline Sulfate & 50000 & $5.21 \times 10^{-04}$ \\
\hline Strontium & 618 & $7.05 \times 10^{-06}$ \\
\hline Tin & 216 & $1.82 \times 10^{-06}$ \\
\hline Alkalinity $\left(\mathrm{CaCO}{ }_{3}\right)$ & 116000 & $1.16 \times 10^{-03}$ \\
\hline Uranium & 174 & $7.31 \times 10^{-07}$ \\
\hline
\end{tabular}




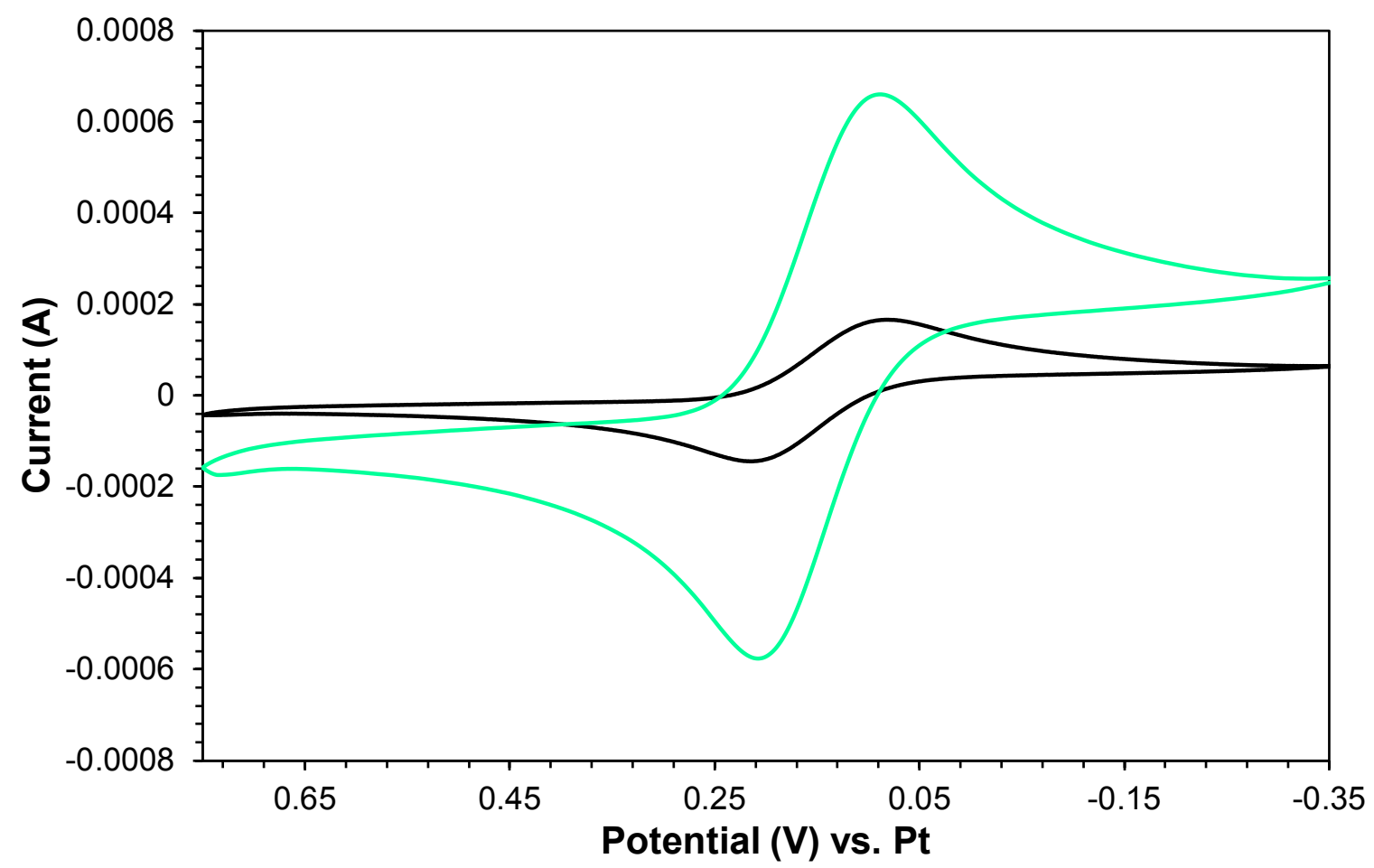

Figure S1. CV (scan rate $=100 \mathrm{mV} / \mathrm{s}$ ) of $0.5 \mathrm{mM}\left[\mathrm{Fe}(\mathrm{CN})_{6}\right]^{4-3-}$ in $0.1 \mathrm{M} \mathrm{KNO}_{3}$ using $(-)$ uncoated and (-)1,4-benzenedimethanethiol coated gold working electrode in the absence of $\mathrm{TcO}_{4}^{-}$. 


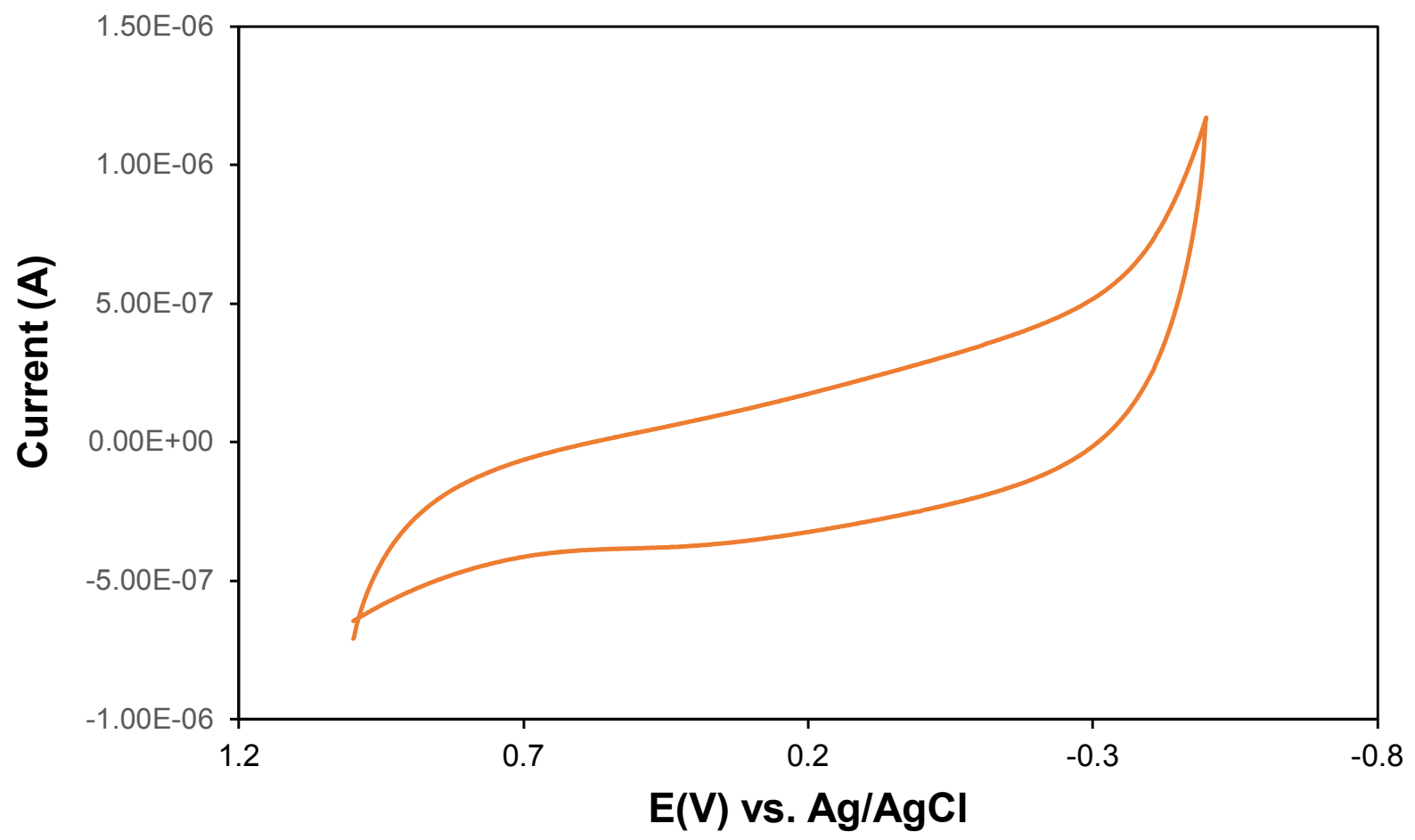

Figure S2. CV (scan rate $=100 \mathrm{mV} / \mathrm{s}$ ) of 1,4-benzenedimethanethiol coated gold working electrode in 0.1 $\mathrm{M} \mathrm{KNO}_{3}$. Coating done on an $\mathrm{Au}$ disc electrode of surface area $0.0314 \mathrm{~cm}^{2}$ using a $10 \mathrm{mM}$ of $1,4-$ benzenedithiol in $10 \mathrm{mM}$ of $\mathrm{KOH}$ for 5 minutes. 


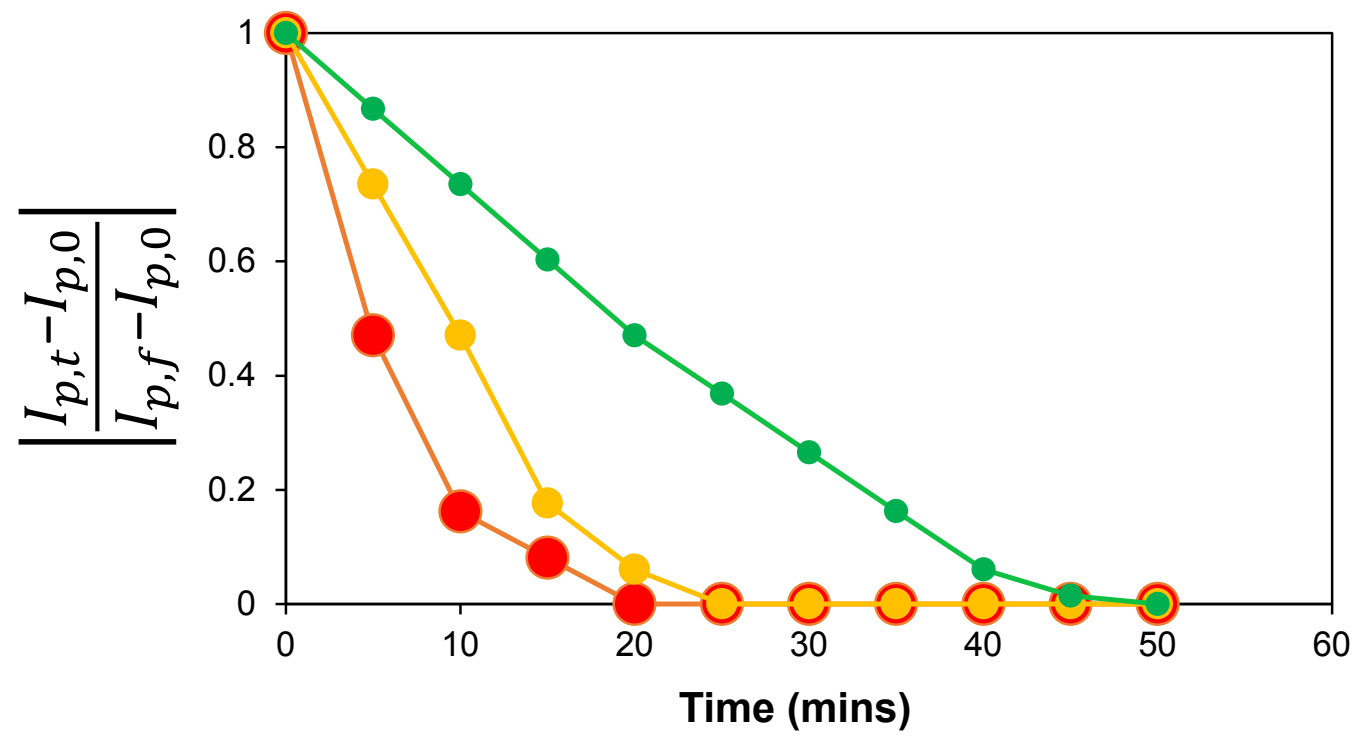

Figure S3. Dependence of peak current intensity ratios with $\mathrm{TcO}_{4}^{-}$exposure time as a function of $\mathrm{pHs}$ : The ratios are calculated from peak currents of DPVs of $0.5 \mathrm{mM}\left[\mathrm{Fe}(\mathrm{CN})_{6}\right]^{4 / 3-}$ in $0.1 \mathrm{M} \mathrm{KNO}_{3}$ using 1 ,4benzenedimethanethiol coated gold working electrode; $\mathrm{TcO}_{4}^{-}$concentration $=6.25 \times 10^{-7} \mathrm{M} \mathrm{TcO}_{4}^{-}$; (red symbols and trace) $\mathrm{pH}=10$; (yellow symbols and trace) $\mathrm{pH}=7$, (green symbols and trace) $\mathrm{pH}=3$. 

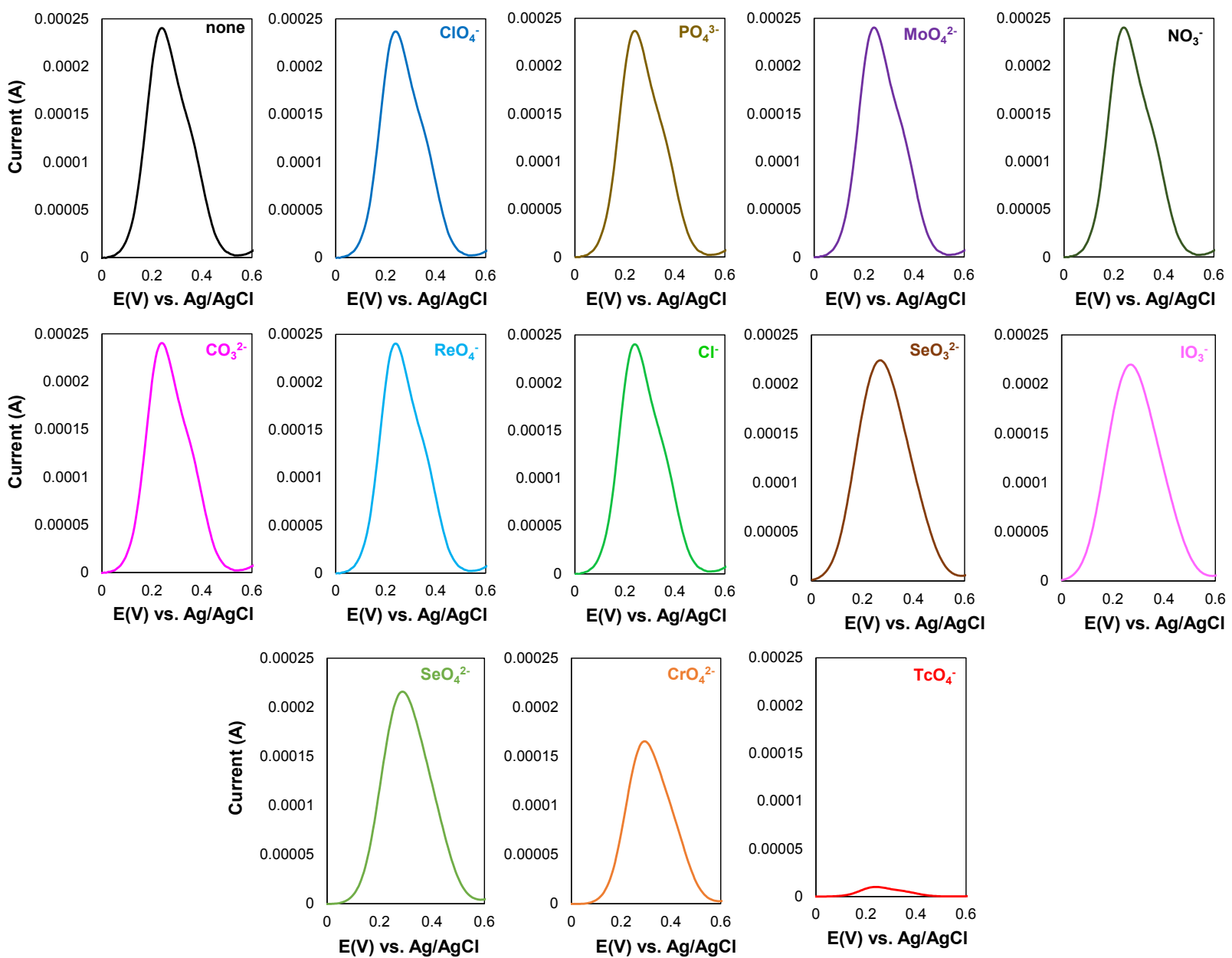

Figure S4. DPVs of $0.5 \mathrm{mM}\left[\mathrm{Fe}(\mathrm{CN})_{6}\right]^{4-3-}$ in $0.1 \mathrm{M} \mathrm{KNO}_{3}$ using 1,4-benzenedimethanethiol coated gold working electrode post exposure to $2 \mathrm{mM}$ of different anions. For $\mathrm{TcO}_{4}^{-}$exposure, $0.2 \mathrm{mM} \mathrm{TcO}_{4}^{-}$was used. 


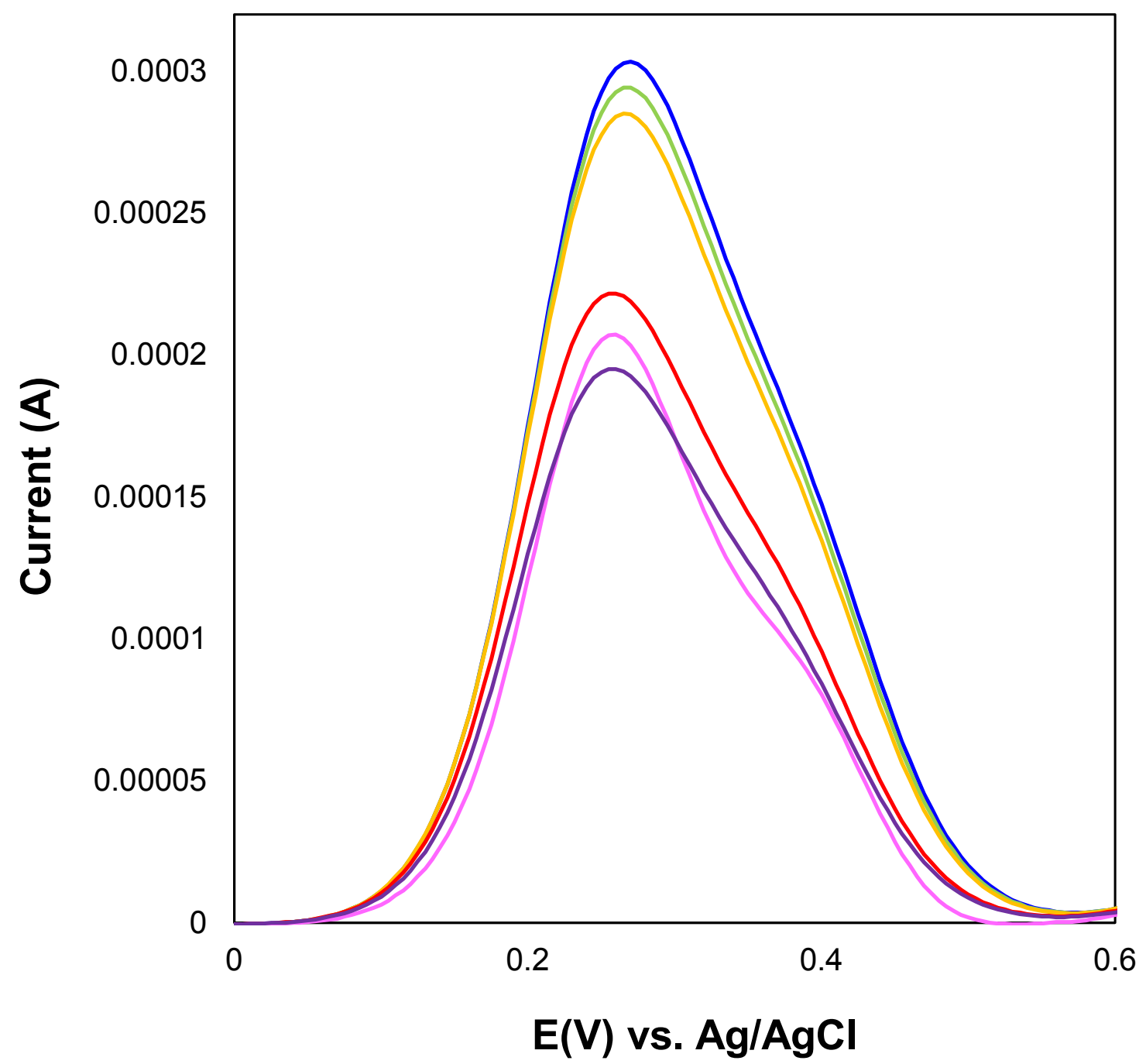

Figure S5. DPVs of $0.5 \mathrm{mM}\left[\mathrm{Fe}(\mathrm{CN})_{6}\right]^{4-3-}$ in $0.1 \mathrm{M} \mathrm{KNO}_{3}$ using 1,4-benzenedimethanethiol coated gold working electrode post exposure to varying anions in presence of $1 \mathrm{M} \mathrm{NO}_{3}{ }^{-}$in DI water for 40 minutes: (-, blue trace) post exposure to $1 \mathrm{M} \mathrm{NO}_{3}^{-}$, (- green trace) post exposure to a mixture of $5 \times 10^{-10} \mathrm{M} \mathrm{CrO}_{4}^{2-}+$ $5 \times 10^{-10} \mathrm{M} \mathrm{SeO}_{4}{ }^{2-}+5 \times 10^{-10} \mathrm{M} \mathrm{IO}_{3}^{-}+1 \mathrm{M} \mathrm{NO}_{3}^{-},\left(-\right.$, yellow trace) post exposure to a mixture of $5 \times 10^{-9} \mathrm{M}$ $\mathrm{CrO}_{4}{ }^{2-}+5 \times 10^{-9} \mathrm{M} \mathrm{SeO}_{4}{ }^{2-}+5 \times 10^{-9} \mathrm{M} \mathrm{IO}_{3}{ }^{-}+1 \mathrm{M} \mathrm{NO}_{3}{ }^{-}$, (-, red trace) post exposure to a mixture of 5 $\times 10^{-10} \mathrm{M} \mathrm{TcO}_{4}^{-}+1 \mathrm{M} \mathrm{NO}_{3}^{-}$, (-, purple trace) post exposure to a mixture of $5 \times 10^{-10} \mathrm{M} \mathrm{TcO}_{4}^{-}+5 \times 10^{-10} \mathrm{M}$ $\mathrm{CrO}_{4}{ }^{2-}+5 \times 10^{-10} \mathrm{M} \mathrm{SeO}_{4}{ }^{2-}+5 \times 10^{-10} \mathrm{M} \mathrm{IO}_{3}{ }^{-}+1 \mathrm{M} \mathrm{NO}_{3}{ }^{-}$, (-, purple trace) post exposure to a mixture of $5 \times 10^{-10} \mathrm{M} \mathrm{TcO}_{4}^{-}+5 \times 10^{-9} \mathrm{M} \mathrm{CrO}_{4}^{2-}+5 \times 10^{-9} \mathrm{M} \mathrm{SeO}_{4}^{2-}+5 \times 10^{-9} \mathrm{M} \mathrm{IO}_{3}^{-}+1 \mathrm{M} \mathrm{NO}_{3}^{-}$. 


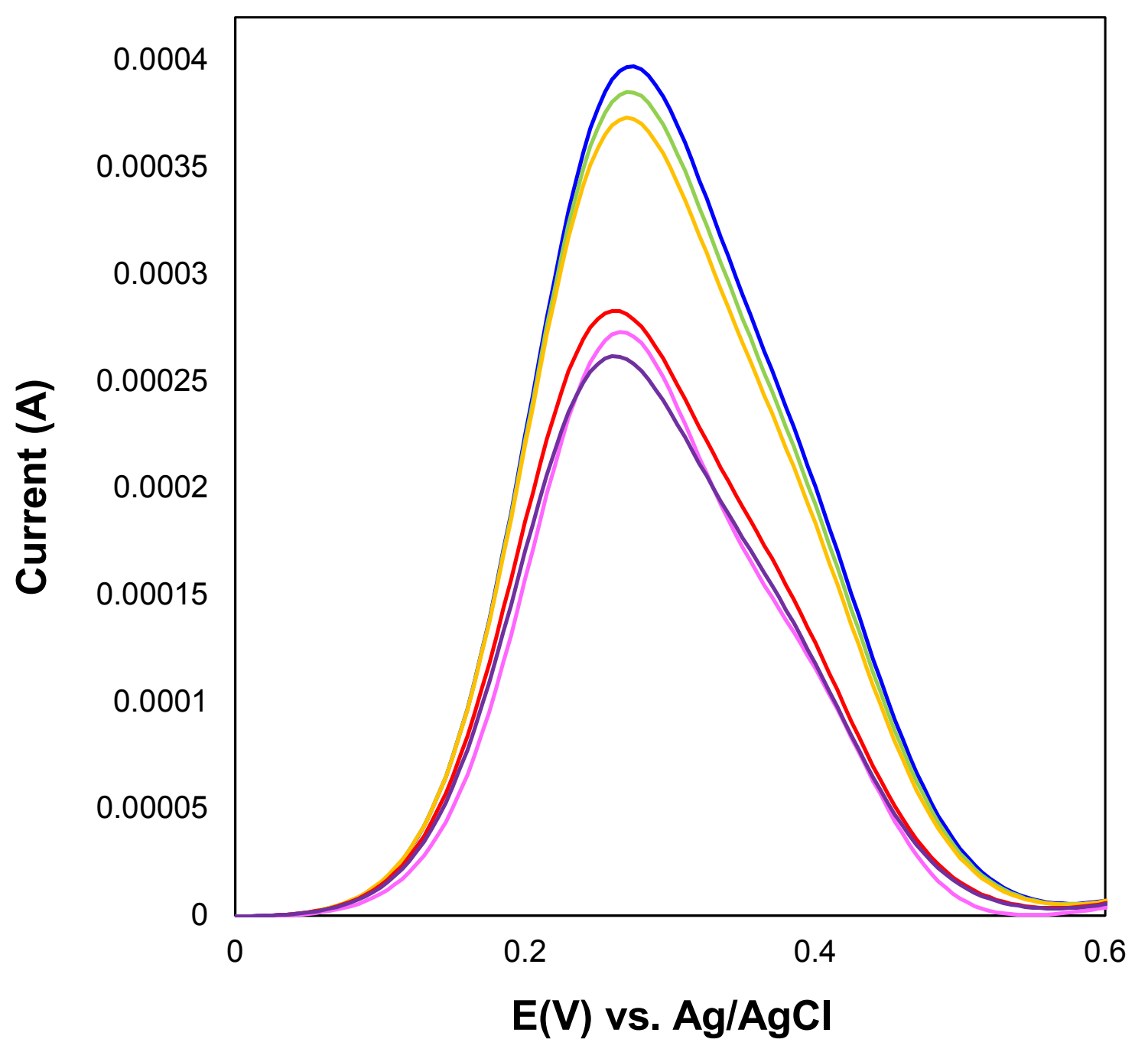

Figure S6. DPVs of $0.5 \mathrm{mM}\left[\mathrm{Fe}(\mathrm{CN})_{6}\right]^{4-3-}$ in $0.1 \mathrm{M} \mathrm{KNO}_{3}$ using 1,4-benzenedimethanethiol coated gold working electrode post exposure to varying anions in presence of simulant $\mathrm{A}$ which is a mixture of $1 \mathrm{M}$ $\mathrm{NO}_{3}{ }^{-}+50 \mathrm{mM} \mathrm{PO}_{4}{ }^{3-}+50 \mathrm{mM} \mathrm{SO}_{4}{ }^{2-}+50 \mathrm{mM} \mathrm{CO}_{3}{ }^{2-}$ in DI water for 40 minutes: (-, blue trace) post exposure to simulant $\mathrm{A},\left(-\right.$, green trace) post exposure to a mixture of $5 \times 10^{-10} \mathrm{M} \mathrm{CrO}_{4}{ }^{2-}+5 \times 10^{-10} \mathrm{M} \mathrm{SeO}_{4}^{2-}+5$ $\times 10^{-10} \mathrm{M} \mathrm{IO}_{3}{ }^{-}+$simulant $\mathrm{A},\left(-\right.$, yellow trace) post exposure to a mixture of $5 \times 10^{-9} \mathrm{M} \mathrm{CrO}_{4}{ }^{2-}+5 \times 10^{-9} \mathrm{M}$ $\mathrm{SeO}_{4}{ }^{2-}+5 \times 10^{-9} \mathrm{M} \mathrm{IO}_{3}{ }^{-}+$simulant $\mathrm{A}$, (-, red trace) post exposure to a mixture of $5 \times 10^{-10} \mathrm{M} \mathrm{TcO}_{4}{ }^{2-}+$ simulant $\mathrm{A},\left(-\right.$, purple trace) post exposure to a mixture of $5 \times 10^{-10} \mathrm{M} \mathrm{TcO}_{4}{ }^{-}+5 \times 10^{-10} \mathrm{M} \mathrm{CrO}_{4}{ }^{2-}+5 \times 10^{-10}$ $\mathrm{M} \mathrm{SeO}_{4}{ }^{2-}+5 \times 10^{-10} \mathrm{M} \mathrm{IO}_{3}^{-}+$simulant $\mathrm{A}$, (-, purple trace) post exposure to a mixture of $5 \times 10^{-10} \mathrm{M} \mathrm{TcO}_{4}^{-}$ $+5 \times 10^{-9} \mathrm{M} \mathrm{CrO}_{4}{ }^{2-}+5 \times 10^{-9} \mathrm{M} \mathrm{SeO}_{4}{ }^{2-}+5 \times 10^{-9} \mathrm{M} \mathrm{IO}_{3}{ }^{-}+$simulant A. 


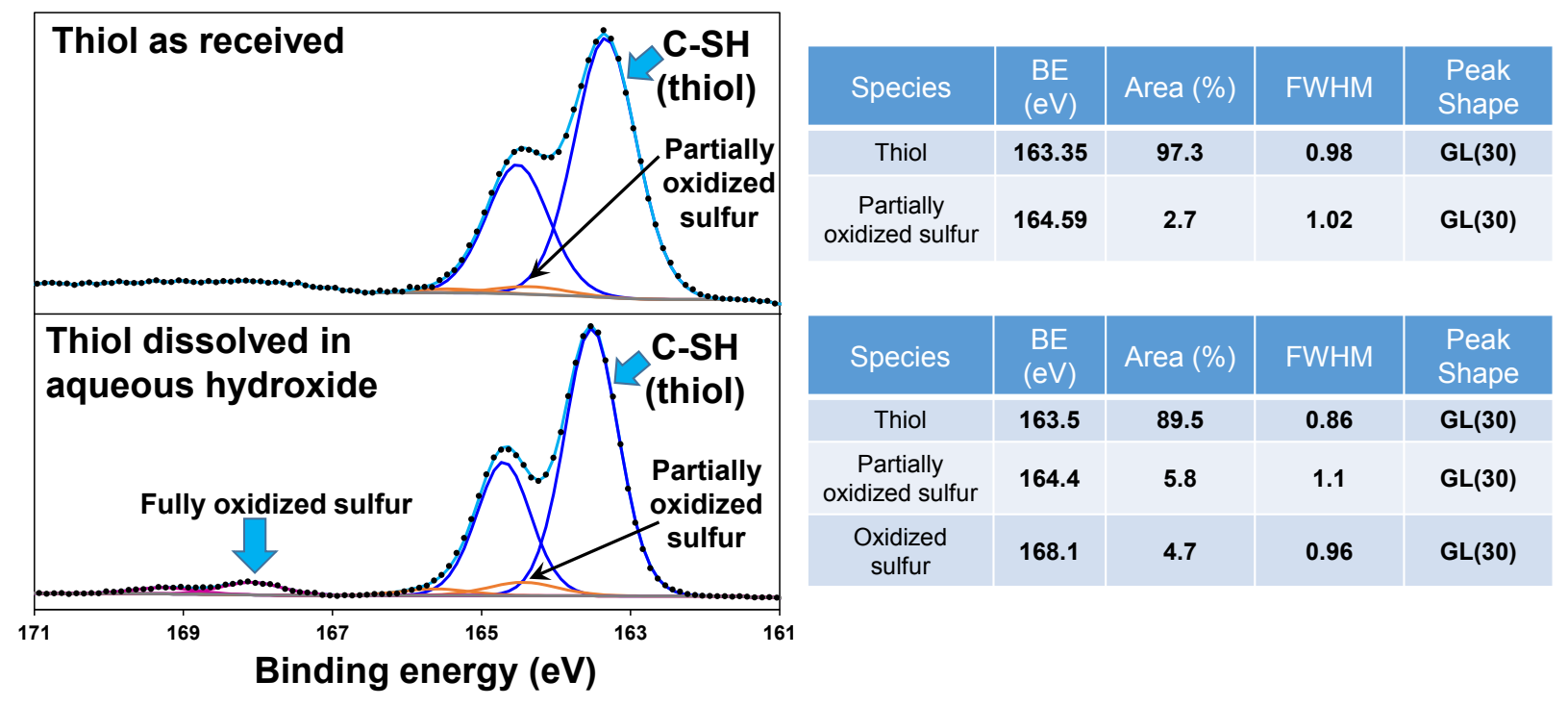

Figure S7. Photoelectron spectra of (top left panel) thiol as received post exposure to air for 30 days and (bottom panel) thiol dissolved in aqueous hydroxide for 7 days. Black symbols represent experimental data, while the blue (light and dark), orange and purple traces represent the spectral fits. The tables on the right panel represent the compiled tabulation of the XPS fits. 